日本臨床麻酔学会第28回大会教育講演

\title{
泰髄鎮痛と交感神経
}

西川精宣*

[要旨] 交感神経系は自律性生理機能に大きくかかわっているが, 痛みの発生や持続 にも関与しており，特に難治性疼痛の治療を考えるうえで検討すべき領域である．脊 賄鎮痛，つまり薬剤の脊髄くも膜下投与と硬膜外投与を含んだ主として脊賄への直接 効果による鎮痛法は, 薬刘投与量の減量, 副作用の軽減や作用時間の延長を期待でき る. ネオスチグミンを除き, 交感神経抑制が同時に生じる薬剤が多いが, 少なくとも 末梢交感神経遮断は痛覚過敏減弱にあまり影響していないようである. 体内埋め込み 型のくも膜下カテーテル注入装置は難治性疼痛治療の新たな展開をもたらす可能性が あり, 脊髄レベルでの交感神経遮断の役割を明らかにしていくことは意義があると考 える.

キーワード : 脊髄鎮痛, 交感神経系, 神経成長因子, 硬膜外投与, 脊髄くも膜下投与

（日臨麻会誌Vol.30 No.5, $717 ～ 726,2010$ )

はじめに

交感神経系は循環や体温調節をはじめとした自律 性生理機能に大きくかかわっているが, 痛みの発生 や持続にも関与しており, 特に難治性疼痛の治療を 考えるうえで検討すべき領域である。脊髄鎮痛，つ まり薬剂の脊髄くも膜下投与と硬膜外投与を含んだ 主として脊髄への直接効果による鎮痛法は, 薬剂投 与量の減量, 副作用の軽減や作用時間の延長を期待 できる。

ここでは, 脊髄鎮痛法を念頭において, 痛みと交 感神経のかかわり，用いられる薬剤と各薬剤の交感 神経活動に及ぼす影響, 神経障害性疼痛に対する交 感神経遮断の役割について概説する。

\section{I 痛みと交感神経のかかわり}

交感神経が痛みに及ぼす関連を説明するときによ く用いられるのが，1943年に提唱された古典的な 「Livingstonの痛みの悪循環説」1), つまり交感神経 興奮反応による悪性サイクルによって痛みが持続あ るいは増悪するというものであるが(図1), 慢性疼 痛をこの理論で画一的には説明できない。これに は，慢性疼痛では春髄後角で中枢性感作が生じてい ることが関係している．刺激によってさまざまな興 奮性カスケードが活性化されて, 脊髄後角侵害受容 ニューロンの興奮性と反応性の増大が生じ, 痛みが 持続する。一方, シナプス前には $\mathrm{GABA}_{\mathrm{A}}, \mathrm{GABA}_{\mathrm{B}}$, $\mu, \delta$ オピオイド受容体, $\alpha_{2}$ 受容体, $5-\mathrm{HT}_{3}$ 受容体, シナプス後には $\mathrm{GABA}_{\mathrm{A}}, \mathrm{GABA}_{\mathrm{B}}, \mu, \delta$ オピオイ 


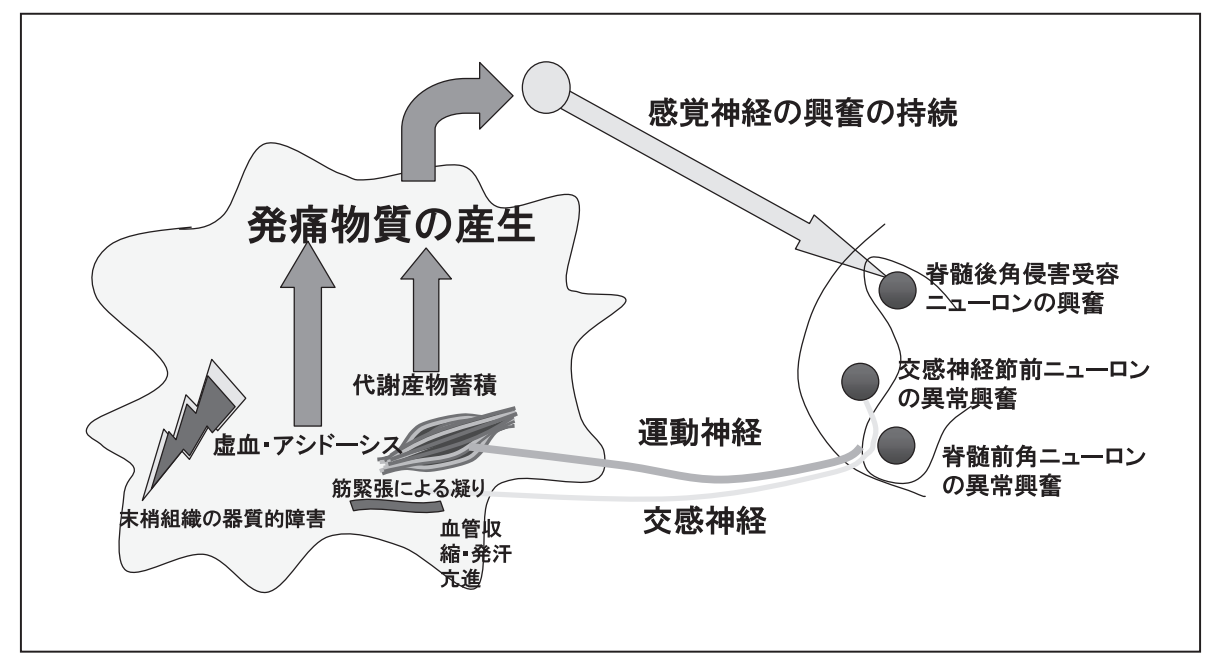

図1 Livingstonの痛みの悪循環説

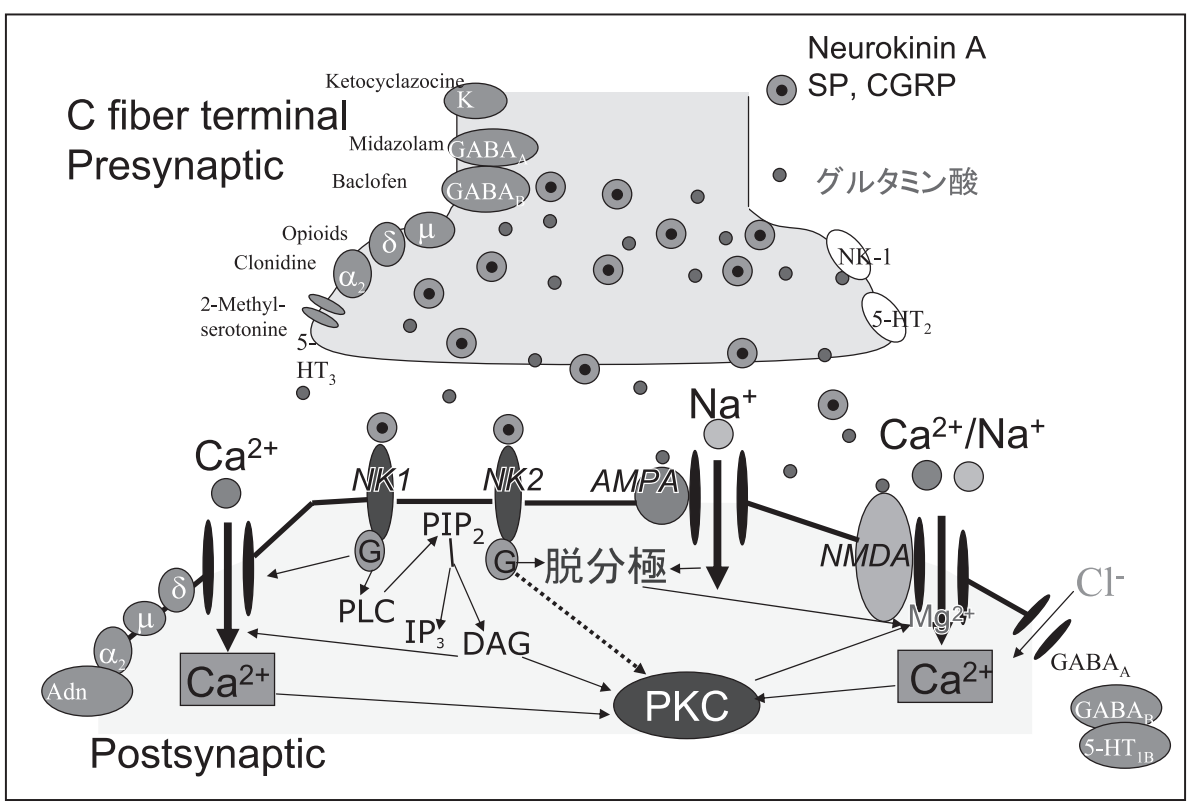

図2 脊䯣後角における中枢性感作

ド受容体， $\alpha_{2}$ 受容体，アデノシン受容体や $5-\mathrm{HT}_{1 \mathrm{~B}}$ 受容体があって興奮の抑制にかかわっている (図2).

\section{1. 交感神経線維の発芽：神経成長因子と慢性疼痛}

慢性疼痛の成立には神経成長因子 (NGF) と交感 神経線維の発芽が大きくかかわっている。NGFの 局所投与でも痛みが発生することが知られている. NGF は，組織損傷によって局所にマクロファージ
が遊走し IL-1や TNF- $\alpha$ を放出すると，線維芽細 胞, 角化細胞, シュワン細胞から分泌され, NGF の受容体であるチロシンキナーゼ型受容体 (trkA : tropomyosin receptor kinase A)をもつ肥満細胞や 交感神経節後線維, 侵害受容ニューロンを刺激する。 肥満細胞からはヒスタミン，セロトニン，ブラジキ ニン，プロスタグランジンなどが遊離されて侵害受 容ニューロンを刺激する(図3)。 


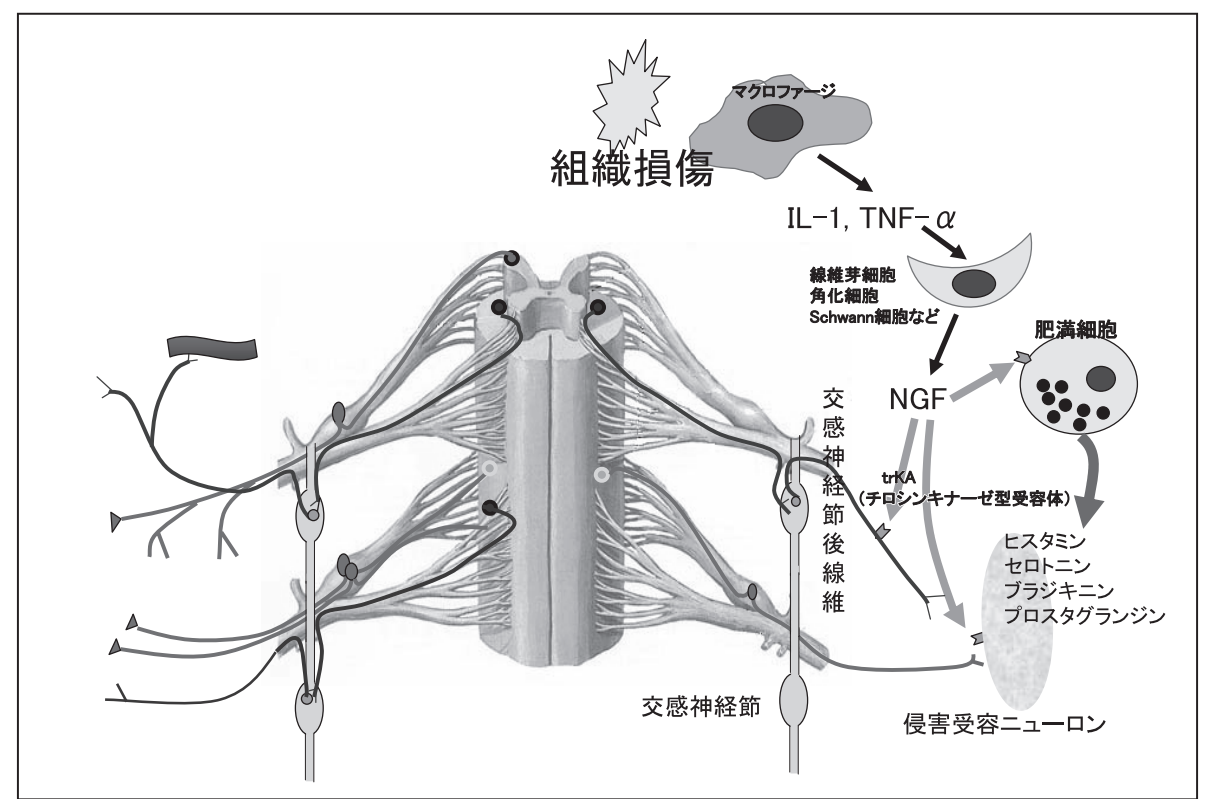

図3 組織損傷と NGF 産生

交感神経依存性疼痛 (sympathetically maintained pain)の原因としては，神経損傷部位で発芽 (sprouting)が起こり, 交感神経節後線維が後根神経節細胞 や末梢痛覚神経と連絡することや，神経障害性疼痛 部位に神経支配を残す非傷害分節知覚神経軸索のア ドレナリン $\alpha_{2}$ 受容体に upregulation が起こること が考えられており，その病態にはNGFが重要な役 割を演ずる。

Jonesらの研究 ${ }^{2)}$ では，NGFを神経障害のないラ ットの脊髄くも膜下に投与すると，14日目には広 範な交感神経線維の発芽がみられ, 腰䯣後根神経節 内の細胞周囲には交感神経線維のバスケットが形成 される。このバスケットは NGF受容体 (trkA)の有 無にかかわらず分布している。

NGF を投与しなくても，坐骨神経切断ラットの ように末梢で侵害受容ニューロンが損傷を受ける と，神経損傷によって内因性にNGFが分泌されて 損傷部位の交感神経節後線維が発芽し後根神経節の 細胞体に向かって伸びてゆく.14〜21日目には, 損傷を受けた侵害受容ニューロンの細胞体にも，損 傷を受けていない侵害受容ニューロンの細胞体に
も，同じように交感神経節後線維が取り巻くように バスケットを形成する (図 4)。末梢受傷部位に NGF 受容体の隔離抗体 (trkA-IgG) を投与しても，障害 ニューロン，非障害ニューロンにバスケットが発現 する比率は変化がない.

脊髄くも膜下にNGF を投与しておいたラットの 後根神経節一未梢神経摘出標本にノルアドレナリン をbath投与して細胞内記録を行うと，69\%に脱分

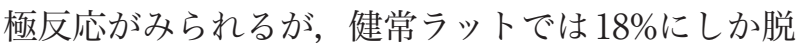
分極反応が出ない ${ }^{3}$. つまり，バスケットを形成し た交感神経と知覚ニューロン細胞体との間にノルア ドレナリンを介した機能的な連絡があることを示し ており, 次の異所性 $\alpha_{2}$ 受容体の発現が関係してい ると考えられる。

\section{2. 異所性 $a_{2}$ 受容体}

神経損傷を受けた侵害受容ニューロンは，末梢に $\alpha_{1}$ 受容体が増加し, 細胞体には異所性 $\alpha_{2}$ 受容体が 増加する．損傷ニューロンの中枢端には神経腫が形 成され，ここにも交感神経節後線維は側枝を伸ばし てゆくので，ここにも異所性 $\alpha_{2}$ 受容体が増加する (図4参照). 


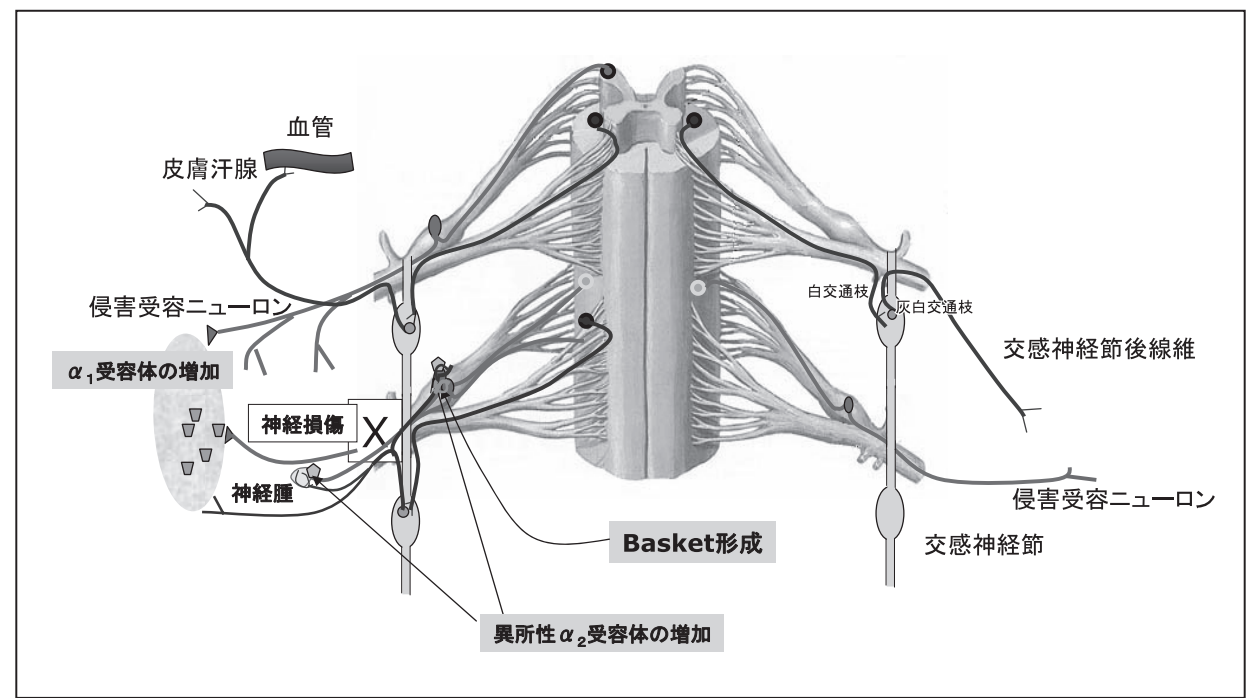

図4 侵害受容ニューロンの損傷と交感神経遠心性線維の発芽

ラット坐骨神経結紮による神経障害性疼痛モデル では，後根神経節内もしくは近辺の $\mathrm{C}, \mathrm{A} \delta, \mathrm{A} \beta$ 線維から自発的な異所性発火を認める ${ }^{3)}$.

ノルアドレナリンあるいはクロニジンを後根神経 節に投与すると，障害神経では C 線維， $\mathrm{A} \delta$ 線維， $\mathrm{A} \beta$ 線維の多くに反応がみられるが，非障害神経で は自発的発火をみるのはまれであり高濃度のノルア ドレナリン，クロニジンにも反応しない。つまり， 神経障害性疼痛の発生には, 障害神経での $\alpha_{1}$ 受容 体および $\alpha_{2}$ 受容体の増加が関与していると考えら れる。機能的に $\alpha_{2 \mathrm{~A}}$ アドレナリン受容体を欠損させ たマウスや，交感神経切除した wild-type マウスで は神経障害性熱過敏が起こらないので, 熱過敏の進 展には交感神経節後ニューロンと知覚神経 $\alpha_{2 \mathrm{~A}}$ アド レナリン受容体の両者のカップリングが寄与してい ると考えられている ${ }^{4)}$.

さて, クロニジン等の $\alpha_{2}$ アゴニストは実際には 鎮静や鎮痛補助目的に全身投与したり，局所麻酔薬 に添加して末梢神経ブロックに用いられたりする. In vitroの電気生理学的研究においては， $\alpha_{2}$ 受容体 刺激が侵害受容ニューロンの興奮を誘発する。しか し, in vivoの行動学的研究では, 神経障害部位の 神経周囲へクロニジンを投与すると, むしろ痛覚過
敏の減弱が長く持続する。一方，局所麻酔薬投与や くも膜下クロニジン投与の効果は一過性である。臨 床においては，ヒトの慢性疼痛で神経周囲へのクロ ニジン投与による痛みの誘発や悪化の報告はない.

障害神経周囲のクロニジン投与で痛みが増さない 理由としては，障害神経周囲の免疫細胞にも $\alpha_{2}$ 受 容体が発現しており，単球からの TNF- $\alpha$ 放出抑制 やNGF 産生・運搬の抑制などの作用を介して中枢 性感作を抑制するのではないかと考えられている5

\section{II 脊髄鎮痛に用いる薬㓮と交感神経に対する作用}

局所麻酔薬以外にも，脊髄くも膜下投与で鎮痛効 果が動物実験等で認められている薬剤を表 1 に列挙 した。脊髄くも膜下に投与する薬剤は神経毒性と副 作用の有無が薬剤の臨床使用への応用の鍵を握る.

交感神経系は中枢神経から末梢に至る広い部分が 関与している。交感神経の高位中枢である視床下部 外側野，室傍核，中脳灰白質核，Kölliker-Fuse核 から興奮性の刺激を受けて, 首座である延髄吻側腹 外側野で調節され，ここから脊髄の中間質外側細胞 核 (IML)，つまり交感神経節前ニューロンの細胞体 の集合へはグルタミン作動性ニューロンが興奮性刺 激を送る。IMLから交感神経節あるいは副腎に至 
表 1 くも膜下投与によって鎮痛作用を示す薬物

\begin{tabular}{|c|c|c|c|c|}
\hline 分類 & 薬剂 & くも膜下使用量 & 神経毒性 & 副作用・その他 \\
\hline オピオイド & $\begin{array}{l}\text { モルヒネ } \\
\text { フェンタニル } \\
\text { スフェンタニル } \\
\text { ペチジン }\end{array}$ & $\begin{array}{l}0.05 \sim 0.3 \mathrm{mg} / \text { day } \\
5 \sim 25 \mu \mathrm{g} \\
4 \sim 10 \mu \mathrm{g} \\
10 \sim 30 \mathrm{mg}\end{array}$ & $\begin{array}{l}\text { なし } \\
\text { なし } \\
\text { 臨床使用量で } \\
\text { は問題なし } \\
\text { 不明 }\end{array}$ & $\begin{array}{l}\text { 長時間鎮痛, 遅発性呼吸抑制, PONV, 掻痒感, 尿閉 } \\
\text { 脊麻の知覚遮断増強, 早発性呼吸抑制, 搔痒感 } \\
\text { 脊麻の知覚遮断増強, 早発性呼吸抑制, 掻痒感 } \\
\text { 局所麻酔作用による脊麻効果, 嘔気 }\end{array}$ \\
\hline $\begin{array}{l}a_{2} \text { 受容体 } \\
\text { 作動薬 }\end{array}$ & $\begin{array}{l}\text { エピネフリン } \\
\text { クロニジン } \\
\text { デクスメデトミジン }\end{array}$ & $\begin{array}{l}0.1 \sim 0.6 \mathrm{mg} \\
15 \sim 45 \mu \mathrm{g} \\
100 \mathrm{ng} \text { (ヒト) }\end{array}$ & $\begin{array}{l}\text { なし } \\
\text { なし } \\
\text { 安全性未確認 }\end{array}$ & $\begin{array}{l}\text { 血管収縮による春麻延長作用もある } \\
\text { 低血圧，徐脈，本邦では注射剤なし } \\
\text { 低血圧，徐脈 }\end{array}$ \\
\hline$M_{1}$ 受容体作動薬 & ネオスチグミン & $6 \sim 100 \mu \mathrm{g}$ & なし & 嘔気嘔吐, 下肢脱力感, 血圧 $\cdot$ 心拍数上昇 \\
\hline GABA 作動薬 & $\begin{array}{l}\text { バクロフェン } \\
\text { (GABALON) }\end{array}$ & $0.01 \sim 0.4 \mathrm{mg} / \mathrm{day}$ & なし & めまい, 倦怠感, 起立性低血圧 \\
\hline NMDA 拮抗薬 & $\begin{array}{l}\text { ケタミン } \\
\text { CPP }\end{array}$ & $\begin{array}{l}<0.3 \mathrm{mg} / \mathrm{kg} \\
<100 \mathrm{nM}\end{array}$ & $\begin{array}{l}\text { 報告あり } \\
\text { 安全性未確認 }\end{array}$ & 鎮静 \\
\hline $\begin{array}{l}\mathrm{N} \text { 型 } \mathrm{Ca}^{2+} \text { チャネ } \\
\text { ル拮抗薬 }\end{array}$ & $\begin{array}{l}\text { ジコノタイド } \\
\text { (PRIALT) }\end{array}$ & $\begin{array}{l}2.4 \mu \mathrm{g} / \mathrm{day} \sim 3 \text { 週間か } \\
\text { けて21.6 } \mathrm{g} / \mathrm{day} ま て ゙\end{array}$ & なし & 吐き気，頭痛，増量で運動障害 \\
\hline 三環系抗うつ薬 & アミトリプチリン & $0.25 \sim 5 \mathrm{mg}$ & 安全性未確認 & 鎮静 \\
\hline $\begin{array}{l}\text { アデノシン } A_{1} \\
\text { 作動薬 }\end{array}$ & R-PIA & $<50 \mathrm{nM}$ & 安全性未確認 & \\
\hline
\end{tabular}

るコリン作動性の交感神経節前ニューロンを経て, ノルアドレナリン作動性の交感神経節後ニューロン が分布する. IMLへは, 縫線核からセロトニン作 動性ニューロンが，A1，A5からはノルアドレナリ ン作動性ニューロンが下降性の調節を行っている. 交感神経終末においては，ノルアドレナリンだけで なく, ATP と Neuropeptide Y (NPY)が血管収縮を 増強したり，修飾物質として働くことが知られてい る。交感神経系を調節する神経伝達物質と興奮性受 容体, 抑制性受容体に分けて, 各部位で示したが, 脊髄鎮痛に用いる薬剤がなんらかの影響はもたらす ことが予想される(表2)。

薬剤の全身投与では交感神経は一般的に一方向性 に変化するが，狭い範囲の薬剤投与や刺激では代償 反応や地域性がみられるので, 目的とする蔵器・器 官に分布する交感神経で計測するべきである。筆者 は循環に関係の深い交感神経心臓枝や腎交感神経と いった交感神経節後線維のニューログラムを導出し ていたが，例えば下肢の交感神経の変化をみるには
下肢の筋交感神経のニューログラムを観察する方法 が適切であろう。

\section{1. 局所麻酔薬}

局所麻酔薬は use-dependentなナトリウムチャ ネルの遮断によって軸索伝導を抑制するが，春髄く も膜下あるいは硬膜外投与では神経の構造的特性も 手伝って交感神経の遮断は必発である。しかしなが ら，イオン電流を遮断する局所麻酔薬の濃度と神経 のシグナル伝達を機能的に遮断する濃度とは関係し ないとされており，軸索伝導抑制を起こさない低濃 度でもシナプス伝導は抑制される ${ }^{6)}$.

2. $a_{2}$ アゴニスト

$\alpha_{2}$ 受容体サブタイプには $\mathrm{A}, \mathrm{B}, \mathrm{C}$ のつがあり, 鎮痛には $\alpha_{2 \mathrm{~A}}$ と $\alpha_{2 \mathrm{C}}$ が関係する。

くも膜下クロニジンの急性痛に対する鎮痛作用 は，脊髄の $\alpha_{2 \mathrm{~A}}$ アドレナリン受容体を介するもので ある。ムスカリン受容体拮抗薬(アトロピン，スコ ポラミン)で抗アロディニア作用はほとんど消失し， ニコチン受容体拮抗薬 (メカミラミン，へキサメト 
表2 交感神経系の neuromodulation

\begin{tabular}{ccc}
\hline 部位 & 興奮性受容体 & 抑制性受容体 \\
\hline 延髄吻側 & $\begin{array}{c}\text { Glu, } \mathrm{M}_{2}, \text { ANGII, } \\
\text { Vasopressin }\end{array}$ & GABA, $a_{2}, \mu$ \\
$\begin{array}{c}\text { 腹外側野 } \\
\text { 交感神経節前 } \\
\text { ニューロン }\end{array}$ & $\begin{array}{c}\text { Glu, } \mathrm{M}_{2}, \mathrm{SP}, \\
\beta, 5-\mathrm{HT} ?\end{array}$ & $\begin{array}{c}\mathrm{GABA}, \mathrm{Gly}, a_{2}, \\
\mu ?, 5-\mathrm{HT} ?\end{array}$ \\
$\begin{array}{c}\text { 交感神経節後 } \\
\text { 二ューロン }\end{array}$ & $\mathrm{NnAch}$ & $a_{2}$ \\
\begin{tabular}{c} 
交感神経終末 \\
\hline
\end{tabular} & $(-)$ & $a_{2}, \mathrm{NPY}, \mathrm{P}_{1}, \mathrm{M}_{2}$ \\
\hline
\end{tabular}

ニウム)でも部分的に減弱する ${ }^{7)}$. また, コリン作 動性ニューロン破壊で抗アロディニア作用は消失す るので，クロニジンの抗アロディニア作用に関して は，アセチルコリンの放出が関係しており ${ }^{8)}$, $\mathrm{GABA}_{\mathrm{B}}$ 受容体の関与もあげられている ${ }^{9)}$.

クロニジンの硬膜外投与は春髄の $\alpha_{2 \mathrm{~A}}$ アドレナリ ン受容体を介して交感神経活動を減少させるが，ク ロニジン $4 \mu \mathrm{g} / \mathrm{kg}$ はリドカイン $2 \mathrm{mg} / \mathrm{kg}$ に匹敵する 交感神経活動の減少を示す ${ }^{10)}$.

デクスメデトミジンのくも膜下投与は，動物実験 で有効性が確認され ${ }^{11), 12)}$ ，オピオイドや $S(+)$-ketamine との間の相乗作用 ${ }^{13)}$, N-type $\mathrm{Ca}^{2+}$ チャネル 拮抗薬との相乗的な mechanical hypersensitivity 抑 制 ${ }^{14)}$ の報告がある。ヒトでの使用報告も散見され， 脊髄くも膜下麻酔に併用して作用時間を延長した という報告や ${ }^{15)}$ ，モルヒネとともに持続くも膜下投 与してがん性疼痛に有効であったという報告 ${ }^{16)}$ が ある。

デクスメデトミジンは硬膜外投与でも用量依存性 にイソフルランの MACを下げ17)，カラゲニン炎症 性疼痛に有効 ${ }^{18}$ である。クロニジン $(10 \sim 500 \mu \mathrm{g})$, チザニジン $(5 \sim 500 \mu \mathrm{g})$ ， デクスメデトミジン $(0.5$ $\sim 10 \mu \mathrm{g})$ は用量依存性に抗侵害作用を示し，その 作用は各薬剂の春髄での親和性に比例する ${ }^{19)}$. しか しながら，デクスメデトミジンのウサギ硬膜外投与 はリドカインに比べ希突起膠細胞の脱髄が有意に多 く ${ }^{20)}$, 神経毒性が懸念される。 ヒトでの硬膜外投与
の報告は少ない.

\section{3. オピオイド}

オピオイドの硬膜外あるいはくも膜下少量投与 は，呼吸抑制，嘔気・嘔吐，掻痒といった副作用出 現に注意すれば現在最も安全に多用される方法であ り，基本的に循環抑制は生じない。しかし，全身麻 酔下の動物実験，高用量投与という特殊な条件で は，モルヒネの硬膜外投与は交感神経活動の減少を もたらす ${ }^{211}$.フェンタニルは交感神経活動の抑制に 関しても脂溶性の高さに基づく分節性があると思わ れる。

\section{4. ネオスチグミン}

ネオスチグミンのくも膜下投与は $\mathrm{M}_{2}$ 受容体刺激 を介して交感神経の著明な刺激作用をもつ。くも膜 下ブピバカインと併用投与すると交感神経活動の減 少を抑え血圧低下を防ぐ 22 .

周術期や周産期の鎮痛に，作用時間の延長や循環 の安定を目的として局所麻酔薬やオピオイドと併用 してネオスチグミンのくも膜下投与が行われていた が，その後のメタアナリシスで嘔気・嘔吐, 徐脈, 不安・興奮・不穏などの短所・副作用が，わずかな 鎮痛改善作用を上回り, 臨床的有用性は限られると いう結論が出された ${ }^{23)}$.

しかし近年，硬膜外投与では，概して副作用の発 生率を上げずに術後鎮痛の改善効果があり, $2 \mu \mathrm{g} /$ $\mathrm{kg}$ 以下の投与量で産科麻酔に安全に使え，仙骨硬 膜外麻酔に併用すると術後痛も改善するといった報 告が多く，復権の兆しがみられる ${ }^{24)}$.

\section{5. ケタミン}

低用量の硬膜外ケタミンは呼吸抑制なく術後痛を 改善する。しかし, pre-emptiveな効果は疑問視さ れている ${ }^{25)}$ 。 また，長期のくも膜下持続投与では, 神経毒性が懸念される ${ }^{26)}$.

ケタミンあるいは $S(+)$-ketamine の硬膜外投与 は，いずれも交感神経活動を減少させる ${ }^{27)}$ 。選択的 競合的 NMDA 受容体拮抗薬で前処置してもケ夕ミ ンによる交感神経抑制は変わらないので，ケ夕ミン 


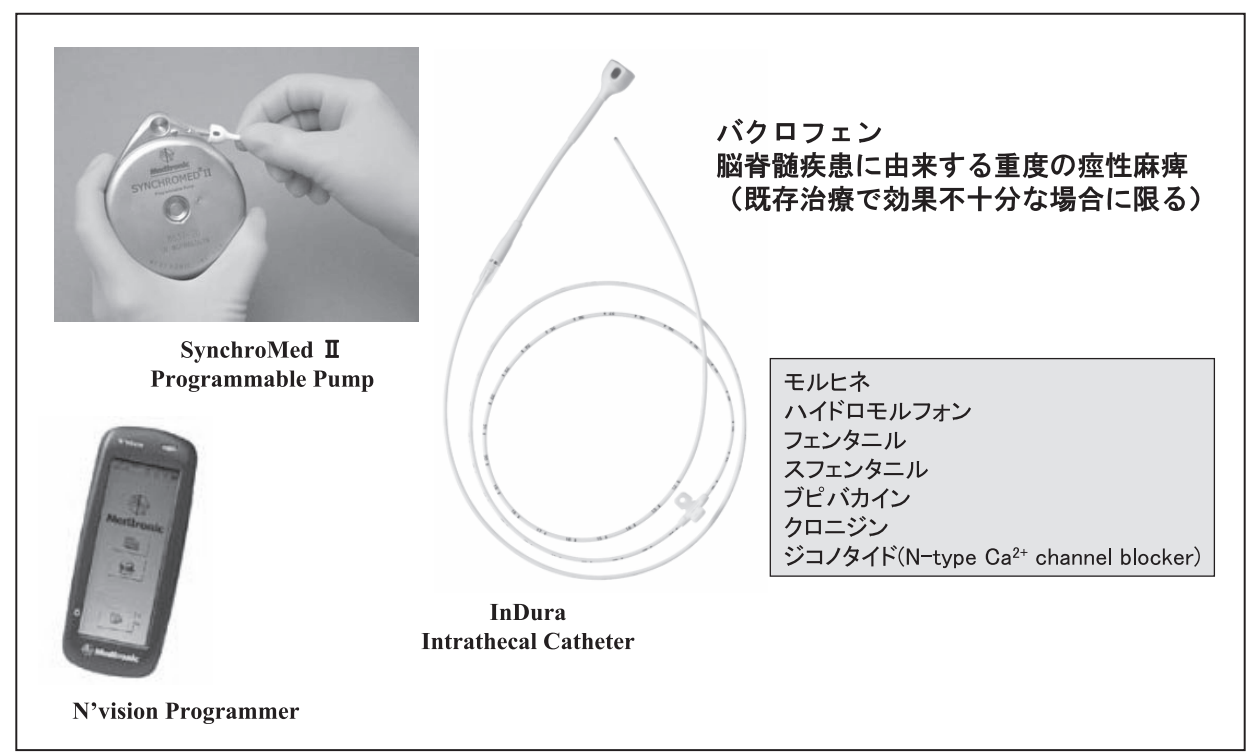

図5 埋め込み型持続くも膜下カテーテル注入装置

が交感神経を抑制する機序はNMDAを介さず，お そらくコリン作動性機序が関係していると考えられ ている ${ }^{28)}$.

上記の脊髄鎮痛薬の交感神経に対する作用はネオ スチグミンを除き抑制性である。

\section{III＼cjkstart神経障害性疼痛と交感神経の役割}

では，交感神経活動の抑制作用は痛み，特に慢性 痛に関して利点があるのだろうか?

残念ながら鎮痛作用の増強の有無について言及し た報告は見当たらない.

神経障害性疼痛を調べるのに，さまざまな動物モ デルが開発され，なかでもChung モデルと呼ばれ る segmental spinal nerve ligation(SNL) model : 脊 髄神経部分結紮モデル ${ }^{29}$ は，交感神経依存性が高く 腰部交感神経節切除でアロディニアが減弱する ${ }^{30)}$. 一方，交感神経の末梢でアドレナリン $\alpha$ 受容体遮断 を行ってもアロディニアは減弱せず ${ }^{31}$, L6 根を結 紮しないでL5根のみを損傷するモデルでは，交感 神経節切除の機械アロディニア減弱効果がない か ${ }^{32)}$, あるいは強く発現したアロディニアにのみ効 果がある ${ }^{33)}$ Ｌ４，L5 脊髄神経結紮モデルにおける 後根神経節でのin vitro記録で，異所性発火は ATP, methylen ATPの投与で増強し，非特異的 $\mathrm{P}_{2 \mathrm{x}}$ 遮断薬で消失したので，ATPがアロディニアの 発症に関係するのではないかと考えられた ${ }^{34)}$.

Neuropeptide YがChung モデルで損傷神経の後 根神経節に発現し, 損傷近位分節で $Y_{2}$ 受容体の増 加がみられるので，発芽交感神経との間でなんらか の調節機構が存在する可能性が考えられている ${ }^{35)}$. Lavand'hommeらは, Chung モデルで交感神経切 除の効果はなく，交感神経活動を増加させる作用を もつネオスチグミンと，交感神経活動を減少させる クロニジンのいずれのくも膜下投与によっても，ア ロディニアは減少した ${ }^{36}$ ので, 交感神経遮断は関与 していないとした。

熱アロディニアの発生に関しては，前にも述べた ように $\alpha_{2 \mathrm{~A}}$ アドレナリン受容体と交感神経節後ニュ ーロン両方の存在が必要である ${ }^{4)}$ 。ところが，末梢 交感神経の化学的破壊を行ってもクロニジンの全身 投与の抗侵害刺激作用は変わらない. したがって, 少なくとも $\alpha_{2}$ アゴニストの抗侵害作用に末梢の交 感神経ニューロンはあまり関係していないと考えら れる ${ }^{4)}$ ，交感神経節前線維を含む春髄レベルでの交 
感神経遮断は発芽した交感神経節後ニューロンの活 動も減少させるので, 疼痛抑制に関与している可能 性は残る。

交感神経遮断そのものの臨床的有用性に関して は，神経障害性疼痛に対するドラッグチャレンジテ ストで，フェントラミンの陽性率が 20\%程度と低い こと, 未梢性の疼痛あるいは神経障害性疼痛の治療 として行われた神経破壊薬あるいは熱凝固を用いた 選択的交感神経切除の長期成績が必ずしも良いもの

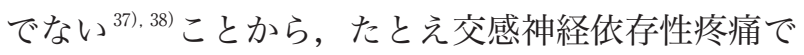
もその適応は慎重に検討すべきである。

\section{IV＼cjkstart臨床における長期のくも膜下薬剤投与}

最近, 薬剤注入速度を外部から調節できる体内埋 め込み型のくも膜下カテーテル注入装置が臨床使用 されている(図5)。投与薬剤は安全性が厳密に検討 されたもののみが使用されるべきである。欧米では 数種類の薬剤の使用が認可されているが，現在の日 本での適応は脳脊髄疾患に由来する重度の痓性麻 痺に対するバクロフェンのくも膜下持続注入に限ら れる。

\section{おわりに}

急性痛，神経障害性疼痛の一部において，交感神 経の緊張，あるいは交感神経の緊張とは関係なくて も交感神経系の構成因子が痛みの持続に関与して いる.

脊髄鎮痛における交感神経遮断の役割を明らかに することで，脊髄鎮痛薬の固有の副作用を減少させ た組み合わせができる。

埋め込み型のくも膜下カテーテル注入装置とい う，臨床にフィードバックできる手段はすでに手に しているわけであり, 神経障害性疼痛に有効で安全 な脊髄鎮痛薬の研究の継続によって, 今後, 難治性 疼痛治療に新たな展開がもたらされることを期待 する.

\section{参考文献}

1) Livingston WK : Pain Mechanisms : A Physiologic Interpretation of Causalgia and Its Related States. Macmillan, Oxford, 1943, 253

2) Jones MG, Munson JB, Thompson SW : A role for nerve growth factor in sympathetic sprouting in rat dorsal root ganglia. Pain $79: 21-29,1999$

3) Zhang JM, Song XJ, LaMotte RH : An in vitro study of ectopic discharge generation and adrenergic sensitivity in the intact, nerve-injured rat dorsal root ganglion. Pain $72: 51-57,1997$

4) Kingery WS, Guo TZ, Davies MF, et al. : The alpha ${ }_{2 \mathrm{~A}}$ adrenoceptor and the sympathetic postganglionic neuron contribute to the development of neuropathic heat hyperalgesia in mice. Pain $85: 345-358,2000$

5) Lavand'homme PM, Ma W, De Kock M, et al. : Perineural alpha $\mathrm{a}_{2 \mathrm{~A}}$-adrenoceptor activation inhibits spinal cord neuroplasticity and tactile allodynia after nerve injury. Anesthesiology 97 : 972-980, 2002

6) Scholz A, Vogel W: Tetrodotoxin-resistant action potentials in dorsal root ganglion neurons are blocked by local anesthetics. Pain $89:$ 47-52, 2000

7) Pan HL, Chen SR, Eisenach JC : Intrathecal clonidine alleviates allodynia in neuropathic rats : interaction with spinal muscarinic and nicotinic receptors. Anesthesiology $90: 509-514,1999$

8) Paqueron X, Li X, Bantel C, et al. : An obligatory role for spinal cholinergic neurons in the antiallodynic effects of clonidine after peripheral nerve injury. Anesthesiology 94 : 1074-1081, 2001

9) Chen SR, Pan HL : Spinal $\mathrm{GABA}_{\mathrm{B}}$ receptors mediate antinociceptive actions of cholinergic agents in normal and diabetic rats. Brain Res $965: 67-74,2003$

10) Ikeda $Y$, Nishikawa K, Ohashi K, et al. : Epidural clonidine suppresses the baroreceptor-sympathetic response depending on isoflurane concentrations in cats. Anesth Analg 97 : 748-754, 2003

11) Joó G, Horvath G, Klimscha W, et al. : The effects of ketamine and its enantiomers on the morphine- or dexmedetomidine-induced antinociception after intrathecal administration in rats. Anesthesiology 93 : 231-241, 2000

12) $\mathrm{Xu} \mathrm{M}$, Kontinen VK, Kalso $\mathrm{E}:$ Effects of radolmidine, a novel alpha2 -adrenergic agonist compared with dexmedetomidine in different pain models in the rat. Anesthesiology $93:$ 473-481, 2000

13) Horvath G, Joo G, Dobos I, et al. : The synergistic antinociceptive interactions of endomorphin-1 with dex- 
medetomidine and/or $\mathrm{S}(+)$-ketamine in rats. Anesth Analg 93 : 1018-1024, 2001

14) Blake DW, Scott DA, Angus JA, et al. : Synergy between intrathecal omega-conotoxin CVID and dexmedetomidine to attenuate mechanical hypersensitivity in the rat. Eur J Pharmacol $506: 221-227,2005$

15) Kanazi GE, Aouad MT, Jabbour-Khoury SI, et al. : Effect of low-dose dexmedetomidine or clonidine on the characteristics of bupivacaine spinal block. Acta Anaesthesiol Scand $50: 222-227,2006$

16) Ugur F, Gulcu N, Boyaci A : Intrathecal infusion therapy with dexmedetomidine-supplemented morphine in cancer pain. Acta Anaesthesiol Scand $51: 388,2007$

17) Campagnol D, Teixeira Neto FJ, Giordano T, et al. : Effects of epidural administration of dexmedetomidine on the minimum alveolar concentration of isoflurane in dogs. Am J Vet Res 68 : 1308-1318, 2007

18) Walker SM, Howard RF, Keay KA, et al. : Developmental age influences the effect of epidural dexmedetomidine on inflammatory hyperalgesia in rat pups. Anesthesiology $102:$ 1226-1234, 2005

19) Asano $T$, Dohi $S$, Ohta $S$, et al. : Antinociception by epidural and systemic alpha ${ }_{2}$-adrenoceptor agonists and their binding affinity in rat spinal cord and brain. Anesth Analg $90: 400-407,2000$

20) Konakci S, Adanir T, Yilmaz G, et al. : The efficacy and neurotoxicity of dexmedetomidine administered via the epidural route. Eur J of Anaesthesiol 25 : 403409, 2008

21) Mori $T$, Nishikawa K, Terai $T$, et al. : The effects of epidural morphine on cardiac and renal sympathetic nerve activity in alpha-chloralose-anesthetized cats. Anesthesiology $88: 1558-1565,1998$

22) Pan HL, Song HK, Eisenach JC : Effects of intrathecal neostigmine, bupivacaine, and their combination on sympathetic nerve activity in rats. Anesthesiology 88 : 481-486, 1998

23) Ho KM, Ismail H, Lee KC, et al. : Use of intrathecal neostigmine as an adjunct to other spinal medications in perioperative and peripartum analgesia : a metaanalysis. Anaesth Intensive Care $33:$ 41-53, 2005

24) Habib AS, Gan TJ : Use of neostigmine in the management of acute postoperative pain and labour pain : a review. CNS Drugs $20: 821-839,2006$

25) Schmid RL, Sandler AN, Katz J : Use and efficacy of low-dose ketamine in the management of acute postoperative pain : a review of current techniques and outcomes. Pain 82 : 111-125, 1999

26) Yaksh TL, Tozier N, Horais KA, et al. : Toxicology profile of $\mathrm{N}$-methyl-D-aspartate antagonists delivered by intrathecal infusion in the canine model. Anesthesiology $108: 938-949,2008$

27) Nishikawa K, Ikeshita K, Ikeda Y, et al. : Epidural $S(+)-$ ketamine and racemic ketamine are equally sympatholytic in anesthetized rabbits. ASA Abstract A83, 2006

28) Ho CM, Su CK : Ketamine attenuates sympathetic activity through mechanisms not mediated by $\mathrm{N}$-meth$\mathrm{yl}-\mathrm{D}$-aspartate receptors in the isolated spinal cord of neonatal rats. Anesth Analg $102: 806-810,2006$

29) Kim SH, Chung JM : An experimental model for peripheral neuropathy produced by segmental spinal nerve ligation in the rat. Pain $50: 355-363,1992$

30) Kim SH, Na HS, Sheen K, et al. : Effects of sympathectomy on a rat model of peripheral neuropathy. Pain $55: 85-92,1993$

31) Ringkamp M, Grethel EJ, Choi Y, et al. : Mechanical hyperalgesia after spinal nerve ligation in rat is not reversed by intraplantar or systemic administration of adrenergic antagonists. Pain $79:$ 135-141, 1999

32) Ringkamp M, Eschenfelder S, Grethel EJ, et al. : Lumbar sympathectomy failed to reverse mechanical allodynia- and hyperalgesia-like behavior in rats with L5 spinal nerve injury. Pain $79:$ 143-153, 1999

33) Lee DH, Katner J, Iyengar S, et al. : The effect of lumbar sympathectomy on increased tactile sensitivity in spinal nerve ligated rats. Neurosci Lett $298:$ 99-102, 2001

34) Zhou J, Chung K, Chung JM : Development of purinergic sensitivity in sensory neurons after peripheral nerve injury in the rat. Brain Res $915: 161-169,2001$

35) Marchand JE, Cepeda MS, Carr DB, et al. : Alterations in neuropeptide $\mathrm{Y}$, tyrosine hydroxylase, and $\mathrm{Y}$-receptor subtype distribution following spinal nerve injury to rats. Pain $79: 187-200,1999$

36) Lavand'homme P, Pan HL, Eisenach JC : Intrathecal neostigmine, but not sympathectomy, relieves mechanical allodynia in a rat model of neouropathic pain. Anesthesiology $89:$ 493-499, 1998

37) Mailis A, Furlan A : Sympathectomy for neuropathic pain. Cochrane Database Syst Rev(2) : CD002918, 2003

38) Gordon A, Zechmeister K, Collin J : The role of sympathectomy in current surgical practice. Eur J Vasc Surg $8: 129-137,1994$ 


\title{
Spinal Antinociception and Sympathetic Nervous System
}

\author{
Kiyonobu NISHIKAWA \\ Department of Anesthesiology, Osaka City University Graduate School of Medicine
}

The sympathetic nervous system is closely linked to autonomic physiological functions, and it also affects pain generation and sustention. Therefore it should be reviewed especially for the treatment of intractable pain. Spinal antinociception, including spinal subarachnoid administration and epidural administration of drugs that directly affect the spinal cord, promises drug sparing, alleviation of side effects and extension of the length of effectiveness. Except for neostigmine, most drugs concomitantly produce suppression of sympathetic nerve activity, however, at least peripheral sympathetic blocking is not involved in alleviation of hyperalgesia. An embedded device that may allow continuous subarachnoid administration of drugs may develop a new treatment for intractable pain. Therefore, disclosing the role of the sympathetic block at the spinal level is valuable.

Key Words : Spinal antinociception, Sympathetic nervous system, Nerve growth factor, Epidural administration of drug, Subarachnoid administration of drug

The Journal of Japan Society for Clinical Anesthesia Vol.30 No.5, 2010 